\title{
The Validity of Student Worksheet Using Inquiry-Based Learning Model with Science Process Skill Approach for Physics Learning of High School
}

\author{
Yulkifli $^{1, a)}$, Melia Vivi Ningrum ${ }^{1, b)}$, Widyaningrum Indrasari ${ }^{2, c)}$ \\ ${ }^{1}$ Physics Department, Faculty of Mathematics and Natural Science, Universitas Negeri Padang, \\ Jl. Prof. Dr. Hamka Air Tawar Padang, Sumatera Barat 25131, Indonesia \\ ${ }^{2}$ Physics Department, Faculty of Mathematics and Natural Science, Universitas Negeri Jakarta, \\ Jl. Rawamangun Muka No.1 13220, Indonesia
}

凶: a)yulkifliamir@gmail.com, b)meliavivi55@gmail.com, ${ }^{\mathrm{c})}$ widyafisikaunj@gmail.com

\begin{abstract}
The significant influence of the 21st century brought a change in Physics learning. Students are required to have the skills to think, work, and live in the surrounding environment. To achieve 21 st-century skills needed teaching materials that can support the learning process.With the presence of teaching materials, students are more active in building their knowledge and easy to understand the material provided. Teaching materials that can guide students with a productive task to practice is the student worksheet. A student worksheet is a teaching material that contains a set of activities to maximize students understanding in achievement of competence. To improve the competence of students, one of the efforts that teachers to develop quality student worksheet. A student worksheet is considered qualified if has validity criteria. The validity assessment of the student worksheet is carried out by expert reviews. This research aims to determine the validity of the student worksheet using an inquiry-based learning model with a science process skills approach. The research conducted is design research using the Plomp model with the type of development studies, where validity is at the stage of development. The research instrument used a validity questionnaire to be filled by expert reviews, then analyzed using Aiken's $\mathrm{V}$ formula. The result of the validity showed that the student worksheet using an inquiry-based learning model with a science process skills approach having valid criteria with a value of 0.88 . It means that the student worksheet is decent for use in Physics learning.
\end{abstract}

Keywords: student worksheet, inquiry-based learning model, science process skills approach, validity

\section{INTRODUCTION}

Learning is a process to support the realization of educational goals. Through learning activities, students are allowed to develop their potential in attitudes, knowledge, and skills to live in their social environment (Kemendikbud, 2013). The achievement of competence in each student is an indicator of the success of learning carried out. The 21 st-century requires that learning be able to produce learners who have various skills to become successful individuals in life. The main objective of 21 st-century learning is to develop students' learning abilities and support their development into lifelong, active, and independent learners. Teachers as a critical component in learning will guide in developing skills and offer a variety of support that will help students achieve their learning goals.

The 21 st-century skill demands are strongly felt by a discipline of Natural Sciences, especially Physics. Physics is a subject related to natural science. Physics is the process of obtaining information through systematic inquiry, scientific attitudes, and critical thinking processes to obtain scientific 
products (Kemendikbud, 2014). Physics learning is carried out using scientific methods to gain knowledge so that students should be directly involved in the learning process, so that competence in themselves develops intact. The critical objective of science education is not only to learn science concepts but rather to build students' competencies for active learning (Huey-Por et al., 2010). Achievement of all competence simultaneously in Physics learning can be through practical activities that can train students to apply theories to real problems, plan activities independently, and train using specific instruments (Darwata et al., 2019). If students are directly involved in building their knowledge, the knowledge gained will last long in themselves. In order to achieve this competency, the teacher, as a facilitator must be able to facilitate students in developing their abilities, such as providing teaching materials in the learning process to facilitate the achievement of learning objectives.

Teaching materials used in the learning process that can develop students' abilities in their entirety are the student worksheet. During the learning process, students are guided by student worksheets to carry out the investigation process in the laboratory supported by practical tools. Yulkifli et al. (2018) suggested that Physics learning is believed to be more practical and time-efficient by using practical tools as its support. The student worksheet contains a set of basic activities that must be done by students to maximize understanding in the effort to form basic abilities following indicators of achievement of learning outcomes that must be taken (Trianto, 2007). Student worksheet as teaching material is needed in the learning process. The function of student worksheet as teaching material includes activating and making it easier for students to understand the learning material as well as a concise and rich task for practice (Prastowo, 2011). Rahayu et al. (2018) state that student worksheets can facilitate students' science process skills. It shows that the availability of student worksheet is one of the factors that can improve students' understanding and skills so that they can improve their competence. Besides, the use of student worksheets in the learning process can change the learning patterns of teacher centers into student centers.

The developed student worksheet contains the steps of the inquiry-based learning model with the science process skill approach. Student worksheet which contains the steps of learning model its orientation can improve students' abilities in analyzing, problem-solving, and scientific work (Yudha et al., 2019).The steps of inquiry-based learning model consisting of five phases, namely orientation, conceptualization, investigation, conclusion, and discussion (Pedaste et al., 2015). Students are directly involved in each phase of inquiry-based learning wherein the student worksheet space is provided for students to learn step by step. The inquiry-based learning model is learning that involves the direct role of students in building their knowledge by conducting experiments (Bayram et al., 2013). The use of inquiry-based learning models in learning can develop all aspects of students. Rodriguez et al. (2019) have conducted research which states that students are very satisfied with their learning experience using inquiry-based learning thereby increasing their complex skills and knowledge. The results of Thaiposri and Wannapiroon (2015) research show that students in the class who use the inquiry-based learning model gain better knowledge and skills. This is in line with the literature review conducted by Utami and Sundari (2019) that inquiry-based learning has an essential role in improving student learning outcomes because they are required to learn actively and solve problems so as to achieve their learning goals. Fernandez (2017) states that students who use the inquiry learning model show significant results in conceptual understanding and success in themselves.

Student worksheet design using an inquiry-based learning model with science process skills approach based on the analysis of the needs, characteristics of learners, material, and assignments. The designed student worksheet has a title contained on the cover, study instructions to guide use, competencies that students will achieve after participating in learning, supporting information presented briefly and clearly, assignments and work steps, and assessment. The student worksheet structure that was compiled refers to the guidelines for the development of teaching materials (Depdiknas, 2008). Activities carried out by students during the learning process are in the tasks and work steps. In this student worksheet, the tasks and work steps are designed clearly and systematically using the five syntaxes of inquiry-based learning models with science process skills approach. Students work according to the tasks and work steps that have been designed. Each task and work step in student worksheet has a section that is filled in by students. It aims to make students active in building knowledge and developing attitudes and skills through direct activities that their do. The assessment included in the student worksheet is only on the aspect of knowledge while for the aspects of attitudes 
and skills in the form of an observation sheet. Every activity undertaken by students is assessed according to the steps of the inquiry-based learning model.

Learning using the inquiry-based learning model with the science process skills approach can build students into individuals who are not only able to access information but also understand where the information is obtained from. Student worksheet uses an inquiry-based learning model with this science process skill approach being one of the factors that can achieve the expected learning goals. In order for the developed student worksheet to achieve the expected goals, the quality of the student worksheet needs to be seen. One of the criteria for quality student worksheet is having high validity. Valid means that the instrument can be used to measure what should be measured (Sugiyono, 2012). Analysis of the suggestions and validation sheets from experts is used as a basis for refinement or revision of the student worksheet design.

\section{METHODS}

The research conducted was design research using the Plomp model of development studies type. Design research according to Plomp (2013), includes systematic studies of designing, developing, and evaluating educational interventions. The development studies include three phases, namely preliminary research, development or prototyping phase, and assessment phase. Validity is at the development stage. The components of student worksheet validity include content, construction, language, and graphics. The previous research about worksheet validity also using this model (Trisna \& Rahmi 2012). According to Depdiknas (2008) a product observation sheet in the form of a questionnaire was used to assess the feasibility of the product that had been designed. The validity assessment of student worksheet uses an inquiry-based learning model with a science process skills approach carried out by experts who are experienced in their fields. Before evaluating the validity of the student worksheet, the validity of the instrument used is tested first. Instruments to assess the validity of student worksheets were assessed by three expert review YL, RA, and HD using the instrument validity assessment sheet. The questionnaire that was filled in by the expert review was analyzed to determine the validity of the instrument. A valid instrument is used to assess the validity of the student worksheet. Furthermore, the questionnaire that was filled in by experts was then analyzed to determine the validity of the developed student worksheet. Validity analysis uses a Likert scale with steps (a) Giving a score for each answer item strongly agree (4), agree (3), disagree (2), and strongly disagree (1), (b) Add up the total score of each expert review for all indicators, (c) Providing validity values using the Aiken's $\mathrm{V}$ formula such as equation (1).

$$
V=\frac{\sum s}{[n(c-1)]}
$$

with: $\mathrm{s}=\mathrm{r}-\mathrm{lo}, \mathrm{lo}=$ the lowest validity score (in this case $=1$ ), $\mathrm{c}=$ the highest validity score (in this case $=4), r=$ the number given by the expert review. Validity categories can be seen in TABLE 1.

TABLE 1. Validity Category

\begin{tabular}{cc}
\hline Value & Category \\
\hline$\geq 0.6$ & Valid \\
$<0.6$ & Invalid \\
\hline
\end{tabular}

(Source: Azwar, 2015)

Based on TABLE 1 can be seen the criteria of the agreement value of the validity obtained. This validity is done using the Aiken's $\mathrm{V}$ formula and is categorized into two values namely valid and invalid. The instrument and student worksheet developed can be said to be valid when the value obtained exceeds or equals 0.6.

\section{RESULTS AND DISCUSSION}

The student worksheet that has been designed is validity tested. The purpose of validation according to Asyar (2011), is to obtain recognition and approval of the suitability of the device to the needs so that it is appropriate and suitable for use in learning. Validity was carried out by three lecturers from 
Universitas Negeri Padang. The student worksheet expert review in this study included YH, FM, and HY. Details of the results of the validity are explained as follows.

\section{Results of Instrument Validity}

Before doing product validity, the validity of the instrument to be used is first tested. The instrument was assessed first by three experts using the validity instrument assessment sheet. The component of the instrument validity assessment includes the appropriateness of the statement with the instrument lattice, the instrument can reveal the quality of the content, language, construction, and graphics of the student worksheet and lesson plan, and the instrument has clear and easy to use instructions in the assessment process. The results of the instrument assessment sheet for student worksheets and lesson plan validity are shown in TABLE 2 .

TABLE 2. Results of Instrument Validity Assessment Sheet

\begin{tabular}{|c|c|c|}
\hline Instrumen & $\begin{array}{l}\text { Aiken's V } \\
\text { Value }\end{array}$ & Category \\
\hline $\begin{array}{l}\text { Instrument for Validity of Student } \\
\text { Worksheet }\end{array}$ & 0.87 & Valid \\
\hline Instrument for Validity of Lesson Plan & 0.85 & Valid \\
\hline
\end{tabular}

Based on TABLE 2, the average rating of the instrument validity of the student worksheet and lesson plan by expert review is greater than 0.6 in the valid category. Thus, the student worksheet and lesson plan validity instruments can be used.

\section{Results of Student Worksheet Validity}

The student worksheet that has been designed was validated by three experts. An expert review of student worksheets using an inquiry-based learning model with science process skills approach, including content, construction, language, and graphics. The assessment of content validity and construction validity based on its suitability with the components of the preparation and steps in student worksheets according to the syntax of inquiry-based learning model with science process skill approach. Besides, the assessment of the validity of student worksheets is seen from the language used and graphic, such as the size of the writing, layout in the presentation of student worksheets. The results of the expert review assessment for each component of the student worksheet validity are presented in TABLE 3.

TABLE 3. Results of Student Worksheet Validity

\begin{tabular}{lll}
\hline Validity Component & Aiken's V Value & Category \\
\hline Content & $\mathbf{0 . 8 8}$ & Valid \\
a. Student worksheet component & 0.90 & \\
b. Eligibility for student worksheet contents & 0.86 & Valid \\
Construction & $\mathbf{0 . 8 6}$ & \\
a. The order of construction of student & 1.00 & \\
worksheet & 0.67 & \\
b. Phase 1. Orientation & 0.78 & \\
c. Phase 2. Conceptualization (Questioning) & \\
d. Phase 2. Conceptualization (Hypothesis) & 0.78 & \\
e. Phase 3. Investigation (Experimentation) & 1.00 & \\
f. Phase 3. Investigation (Data Interpretation) & 0.78 & Valid \\
g. Phase 4. Conclusion & 0.89 & Valid \\
h. Phase 5. Discussion (Communication) & 0.89 & Valid \\
i. Phase 5. Discussion (Reflection) & 0.89 & $\mathbf{0 . 9 0}$ \\
Language & $\mathbf{0 . 8 9}$ & $\mathbf{0 . 8 8}$ \\
Graphic &
\end{tabular}


Based on TABLE 3, it can be seen that the average value of the student worksheet validity from the expert review is greater than 0.6. It means that the student worksheet using an inquiry-based learning model with science process skills approach for Physics learning of high school in the valid category.

\section{Results of Lesson Plan Validity}

An expert review of the lesson plan includes content, construction, and language. The assessment on lesson plan for attitude competence using observation sheets, knowledge competence using multiple-choice tests, and performance assessment sheets for skills competence. Expert assessment of the validity of the lesson plan is based on its compatibility with the syntax of the inquiry-based learning model with science process skills approach. The results of the expert review assessment for each component of the lesson plan validity are presented in TABLE 4.

TABLE 4. Results of Lesson Plan Validity

\begin{tabular}{lcc}
\hline \multicolumn{1}{c}{ Component Validity } & Aiken's V Value & Category \\
\hline Content & 0.87 & Valid \\
Construction & 0.89 & Valid \\
Language & 0.89 & Valid \\
\hline \multicolumn{1}{c}{ Average } & $\mathbf{0 . 8 8}$ & Valid \\
\hline
\end{tabular}

TABLE 4 shows the average value of the validity of the lesson plan from the expert review is greater than 0.6. It means that the lesson plan using the inquiry-based learning model with science process skills approach for Physics learning of high school in the valid category. The student worksheet assessed by experts has several improvements to produce better products. Some of the improvements suggested by the expert review in the validation process are summarized in TABLE 5.

TABLE 5. Suggestions for Expert reviews and Revisions to the Student Worksheet

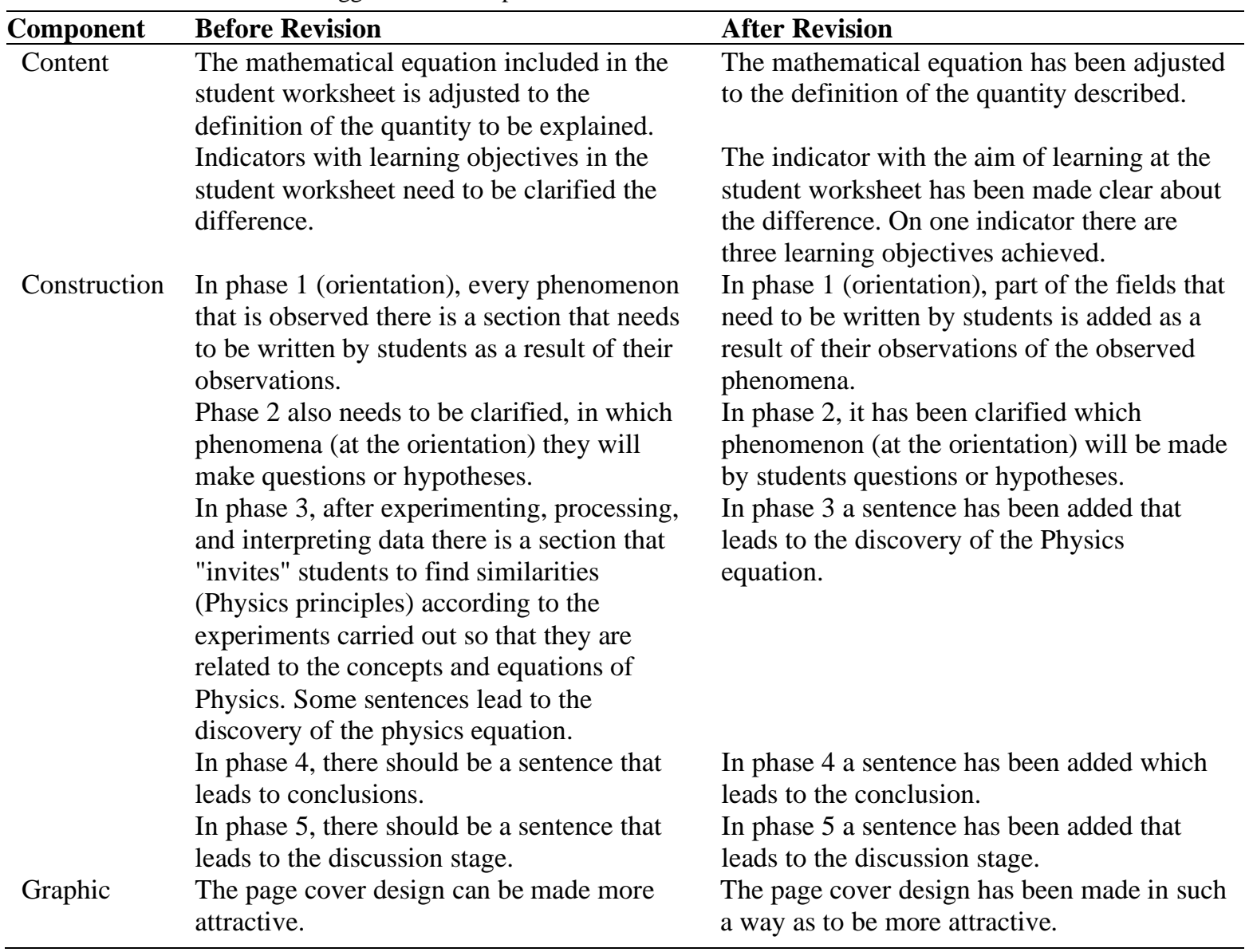




\section{SUMMARY}

The validity of student worksheets using inquiry-based learning model with science process skills approach including content, construction, language, and graphics are valid criteria with an average value of 0.88 . A student worksheet is designed using the step inquiry-based learning model with science process skills approach. First, orientation is displaying phenomena that can arouse students' curiosity to build knowledge. Second, conceptualization which consists of questioning and hypothesis which is facilitating students to formulate problems and build hypothesis based on the phenomena presented. Third, investigation which consists of experimentation and data interpretation, namely facilitating students to investigate and process data. Fourth, the conclusion is to facilitate students to conclude the results of the investigation. Fifth, a discussion consisting of communication and reflection that is to facilitate students to communicate the results of the investigation, discuss understanding concepts with their friends and facilitate students to confirm understanding of the concept to the teacher, and facilitate teachers and students in conducting learning reflection activities. This designed student worksheet makes students more active in building their knowledge and easily understands the material provided because students are involved in every learning process. In addition to the validity of the student worksheet, the lesson plan validity was also carried out. All products that have been developed have valid criteria and decent for use in high school Physics learning.

\section{ACKNOWLEDGMENTS}

The authors acknowledge to the Indonesian Ministry of Research, Technology, and Higher Education for the Grant Research Penelitian Tesis Magister (PTM) 2019, No. Contract: 349/UN35.13/LT/2019.

\section{REFERENCES}

Asyar, R 2011, Kreatif Mengembangkan Media Pembelajaran, Gaung Persada Press, Jakarta.

Azwar, S 2015, Metode Penelitian, Pustaka Pelajar, Yogyakarta.

Bayram, Z, Oskay, OO, Erdem, E, Ozgur, SD, \& Sen S 2013, 'Effect of inquiry-based learning method on students' motivation', Procedia-Social and Behavioral Science, vol. 106, pp. 988-996.

Darwata, SR, Yulkifli, Y, \& Yohandri, Y 2019, 'Validity of student worksheet oriented on POE model as digital practicum tool', IOP Conf. Series: Journal of Physics, vol. 1185, pp. 1-7.

Depdiknas 2008, Panduan Pengembangan Bahan Ajar, Direktorat Pembinaan Sekolah Menengah Atas, Jakarta.

Fernandez, FB 2017, 'Action research in the physics classroom: the impact of authentic, inquiry based learning or instruction on the learning of thermal physics', Asia-Pacific Science Education, vol. 3, pp. 1-20.

Huey-Por, C, Chin-Chang, C, Gwo-Jen, G, Yeong-Jin, C, Chen-Yung, L, \& Tsung-Hau, J 2011, 'The development of a competence scale for learning science: inquiry and communication', International Journal of Science and Mathematics Education, vol. 9, pp. 1213-1233.

Kemendikbud 2013, Peraturan Menteri Pendidikan dan Kebudayaan Nomor 81 A Tahun 2013 Tentang Implementasi Kurikulum, Kemendikbud, Jakarta.

Kemendikbud 2014, Peraturan Menteri Pendidikan dan Kebudayaan Nomor 59 Tahun 2014 Bagian C PMP FIS-Minat SMA, Kemendikbud, Jakarta.

Pedaste, M, Maeots, M, Siiman, LA., Jong, T, Riesesn, AN, Kamp, ET, Manoli, CC, Zacharia, ZC, \& Tsourlidaki, E 2015, 'Phases of inquiry based learning: definition an the inquiry cycle', Educational Reseach Review, vol. 14, pp. 47-61.

Plomp, T 2013, 'Educational Design Research: An Introduction dalam Tjeerd Plomp dan Nienke Nieveen (Eds)', Educational Design Research. Enschede: SLO, pp. 10-51. 
Prastowo, A 2011, Panduan Kreatif Membuat Bahan Ajar Inovatif, Diva Press, Yogyakarta.

Rahayu, YS, Pratiwi, R, \& Indana, S 2018, 'Development of biology student worksheets to facilitate science process skills of student', IOP Conferences Series: Materials Science and Engineering, vol. 296, pp. 1-12.

Rodriguez, G, Perez, N, Nunez GB, Josep-E, \& Carrio M 2019, 'Developing creative and research skills through an open and interprofessional inquiry-based learning course', BMC Medical Education, vol. 19, p. 134.

Sugiyono 2012, Metode Penelitian Pendidikan (Pendekatan Kuantitatif, Kualitatif, dan R\&D), Alfabeta, Bandung.

Thaiposri, P, \& Wannapiroon, P 2015, 'Enhancing students' critical thinking skills through teaching and learning by inquiry-based learning activities using social network and cloud computing', Procedia-Social and Behavioral Science, vol. 174, pp. 2137-2144.

Trianto 2007, Pembelajaran Inovatif Berorientasi Konstruktivistik, Prestasi Pustaka Publisher, Surabaya.

Trisnaa, S, \& Rahmi, A 2016, 'Validitas Modul Pembelajaran Berbasis Guided Inquiry pada Materi Fluida di STKIP PGRI Sumatera Barat', Jurnal Penelitian dan Pengembangan Pendidikan Fisika, vol. 2, no. 1, pp. 9-14.

Utami, S, \& Sundari, S 2019, 'Inquiry-based learning for improving student learning outcomes: literature review', Jurnal Penelitian dan Pengembangan Pendidikan Fisika, vol. 5, pp. 49-62.

Yudha, SFA, Yulkifli, Y, \& Yohandri Y 2019, 'Validity of student worksheet based on guided inquiry learning model assisted by digital practicum tool', IOP Conf. Series: Journal of Physics, vol. 1185, pp. 1-8.

Yulkifli, Y, Afandi, Z, \& Yohandri, Y 2018, 'Development of gravity acceleration measurement using simple harmonic motion pendulum method based on digital technology and photogate sensor', IOP Conf. Series: Materials Science and Engineering, vol. 335, pp. 1-9. 
